\title{
Investigation of the chemical composition of red pigments and binding media
}

\author{
Aušra Čiuladienė ${ }^{\star}$, \\ Austëja Luckutè, \\ Jonas Kiuberis, \\ Aivaras Kareiva \\ Institute of Chemistry, \\ Faculty of Chemistry and Geosciences, \\ Vilnius University, Naugarduko St. 24, \\ 03225 Vilnius, Lithuania
}

\begin{abstract}
This study presents the results of investigation of red pigments and binding media used in ancient manuscripts for rubrication and illumination. The commercial compounds were analysed with the aim to create a short data library which could be used for the characterization of different model compositions of red pigments and dyes. Finally, these analytical data will be used for the identification of specimens obtained from ancient manuscripts. The red pigments and binding media were characterized using Fourier-transform infrared spectroscopy (FTIR), scanning electron microscopy coupled with energy-dispersive X-ray spectroscopy (SEM/EDX), X-ray diffraction (XRD) analysis and thermal (TG/DSC) analysis techniques.
\end{abstract}

Keywords: red pigments, binders, analysis, SEM-EDX, XRD, FTIR, TG/DSC

\section{INTRODUCTION}

Human beings have had an urge to leave their mark in the form of artworks since prehistoric times. This has led to finding new and better pigments. The artists or their apprentices prepared their own pigments from the raw materials, which were mainly mineral materials. The raw material was ground to powder and, if necessary, the pigment has been extracted in processes which basically remained unchanged until this day. The first chemical test for the synthesized pigment was made by Diesbach in Germany in 1704, but only in 19th century some inorganic pigments began to replace organic pigments [1].

In recent years, there has been an increasing interest in historical paint, materials and different types of decoration and painting techniques [2 4 ]. Inks and dyes are typically found in a wide variety

\footnotetext{
* Corresponding author. Email: ausra.ciuladiene@chgf.stud.vu.lt
}

of historical documents, which are usually stored in libraries, museums or archives. Historically, the most common inks are carbon black and iron gall ink [5-7]. Coloured inks and dyes were used to decorate historical documents. The most fragile and precious artworks are ancient manuscripts, which are used to decorate the most illumination and rubrication. Characterization of their decoration palette is an interesting task for conservation and restoration scientists but, with no doubt, a challenging one $[8-10]$. For the characterization of the materials used in the decoration non-invasive analytical methods should be used, however, many museums and restoration centers have techniques that can be classified as micro-destructive ones [11].

The pallet of inorganic pigments includes some hundred different types with their well-known chemical compositions. Each of them is characterized by its colour and by elemental composition. These parameters allow the pigment to be 
identified [ [7] 12]. In this work the historical red pigments were investigated. Six different pigments (cinnabar, red lead, realgar, red ochre, hematite and red bole) and three binding media (gum Arabic, fish glue, parchment glue) were purchased from Kremer Pigmente as a standard and for the first time analysed using FTIR, SEM-EDX, XRD and TGA/DSC analysis techniques.

\section{EXPERIMENTAL}

Six different red pigments: natural cinnabar (HgS, 10610), red lead $\left(\mathrm{Pb}_{3} \mathrm{O}_{4}, 42500\right)$, realgar $\left(\mathrm{As}_{4} \mathrm{~S}_{4}\right.$, 10800), red bolus $\left(\mathrm{Fe}_{2} \mathrm{O}_{3} \cdot \mathrm{SiO}_{2} \cdot \mathrm{Al}_{2} \mathrm{O}_{3}, 40503\right)$, red ochre $\left(\mathrm{Fe}_{2} \mathrm{O}_{3}, 11274\right)$, hematite $\left(\mathrm{Fe}_{2} \mathrm{O}_{3}, 48651\right)$ and three binding media (gum Arabic (63320), fish glue (63080), parchment glue (63035)) were purchased from Kremer Pigmente. The pigment samples were characterized by the X-ray diffraction analysis (XRD) using a Benchtop XRD MiniFlex II, Rigaku. The XRD patterns were measured in the range of 10 to $80^{\circ} 2 \theta, 5^{\circ} / \mathrm{min}$. speed, using $\mathrm{CuKa}_{1}$ radiation. The surface morphology of the samples and the elemental analysis was studied by a scanning electron microscope coupled with energy dispersive X-ray spectroscopy (SEM/ EDX) using a Hitachi TM3000. IR spectroscopy was used for identification and characterization of functional groups of pigments and binding media. Infrared spectra were obtained by a FTIR spectrophotometer Bruker Alpha with an ATR accessory. All spectra were recorded at $4 \mathrm{~cm}^{-1}$ resolution in an interval of $450-4000 \mathrm{~cm}^{-1}$ and 24 scans were accumulated before Fourier transformation. The thermogravimetric analysis (TG) was recorded using a Perkin Elmer pyris TGA instrument. The heating rate was $10^{\circ} \mathrm{C} / \mathrm{min}$ in the air flow from 30 to $900^{\circ} \mathrm{C}$.

\section{RESULTS AND DISCUSSION}

\section{SEM/EDX analysis}

For the determination of the amount of main and trace elements in the pigments and binding media the SEM/EDX analysis method was applied. The results are presented in Figs. 1 and 2 . The SEM micrograph (Fig. 1) shows that cinnabar is composed of plate-like crystals $2-5 \mu \mathrm{m}$ in size. The EDX elemental analysis of cinnabar showed that the amount of mercury in the sample was $72.2 \mathrm{wt} . \%$ and sulfur

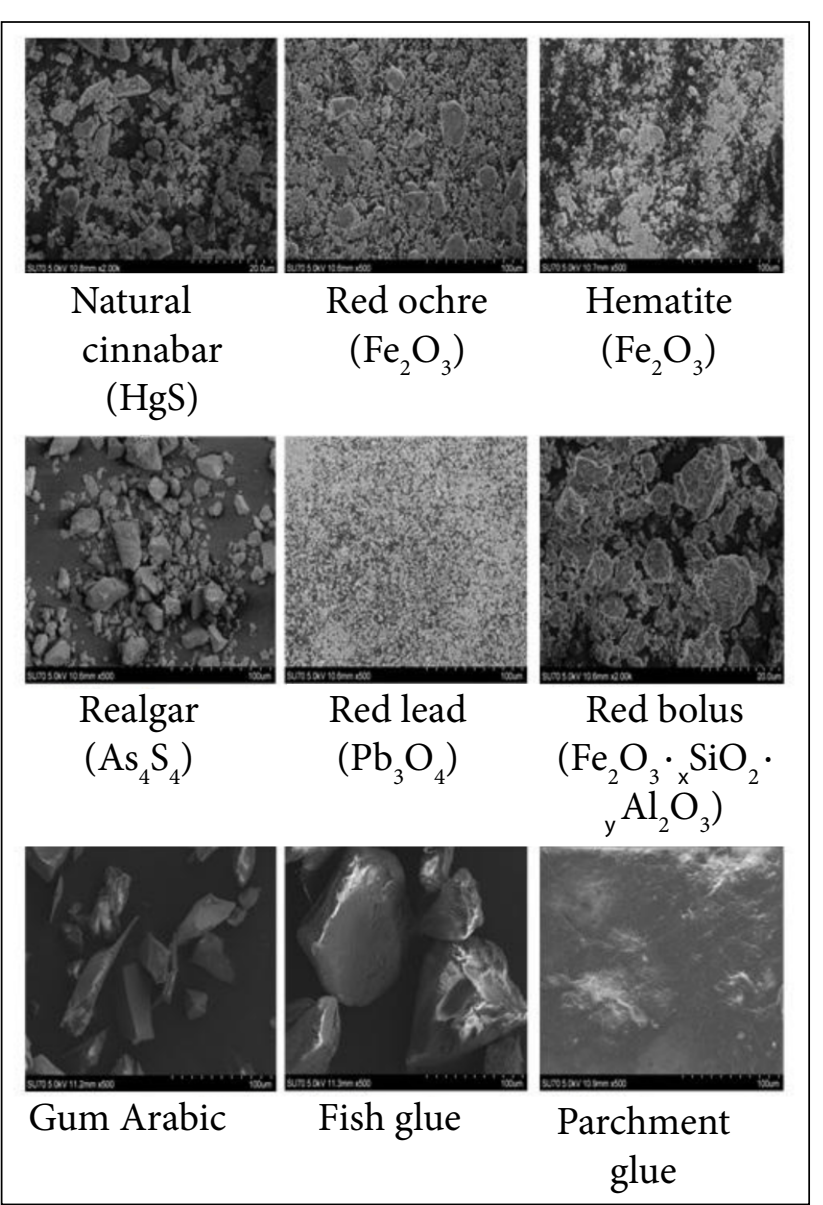

Fig. 1. SEM micrographs of the pigments and binding media

15.7 wt.\% which is consistent with mercury (II) sulphide HgS. Besides, a small amount of Si (5 wt.\%) and $\mathrm{Al}$ (2 wt.\%) was also determined (see Fig. 2). Therefore, it is likely that in addition to HgS there is also a small amount of clay in the commercial cinnabar.

It is well known that the chemical composition of realgar is $\mathrm{As}_{4} \mathrm{~S}_{4}$. The results of the SEM/EDX analysis of commercial realgar are shown in Figs. 1 and 2. According to SEM, the particles of realgar are differently shaped varying in size from 5 to $40 \mu \mathrm{m}$. The EDX data showed that the amount of arsenic was $42.8 \mathrm{wt} . \%$ and that of sulfur $16.4 \mathrm{wt} . \%$. These results are in a good agreement with those calculated for the realgar $\mathrm{As}_{4} \mathrm{~S}_{4}$. The carbon signal visible in the EDX spectrum is from a carbon film used for the sample preparation. The pigment hematite is composed of nanosized particles, the part of which forms spherical agglomerates (Fig. 1). The results of the EDX elemental analysis of hematite showed the highest amount of iron (34.7 wt.\%) and oxygen $\mathrm{O}$ (45.1 wt.\%). However, small amounts 


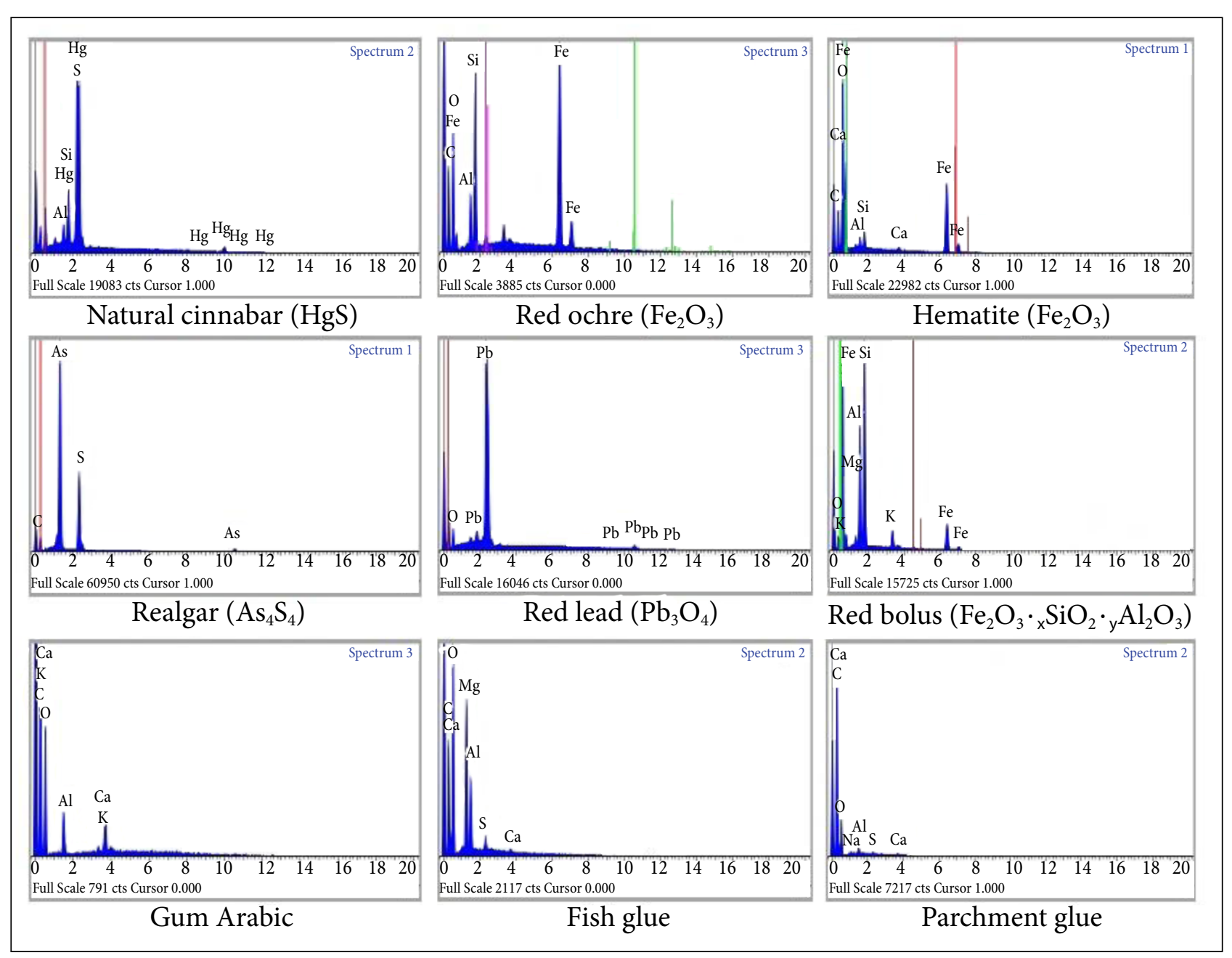

Fig. 2. EDX spectra of the pigments and binding media

of C (17.3 wt.\%), Si (1.4 wt.\%), Al (1 wt.\%) and $\mathrm{Ca}(0.5$ wt.\%) (Fig. 2) were also detected. As seen from the SEM micrograph (Fig. 2), a narrow particle size distribution is evident for the pigment red lead. Moreover, the spherical particles less than $100 \mathrm{~nm}$ are finely distributed within the entire SEM image. The EDX results of the pigment red lead presented in Fig. 2 confirm that the material contains only lead ( 84.5 wt.\%) and oxygen (15.5 wt.\%). The surface microstructure of the pigment red ochre (Fig. 1) is very similar to that of hematite. The EDX results confirmed that the main component of red ochre is iron (III) oxide (Fe 48.2 wt.\% and O 16.8 wt.\%) with a small amount of impurities. These side elements ( $\mathrm{Si}$ and $\mathrm{Al})$ in red ochre can be found in a form of kaolin $\mathrm{Al}_{2} \mathrm{Si}_{2} \mathrm{O}_{5}(\mathrm{OH})_{4}$. The composition of pigment red bolus is very similar to the composition of red ochre (O 48.7 wt.\%, Fe 12.7 wt.\%, Si 16.8 wt.\%, $\mathrm{Al} 8.8$ wt.\%, K 2.3 wt.\% and Mg 0.8 wt.\%). The ob- tained data are presented in Figs. 1 and 2. Thus, the pigment is composed of iron aluminium silicate with some impurities. The particles of this pigment show a plate-like microstructure with a particle size about $2-10 \mu \mathrm{m}$.

Gum Arabic is a complex polysaccharide, either neutral or slightly acidic, found as a mixed calcium salt of polysaccharide acid (arabic acid). The backbone of gum Arabic is composed of 1,3-linked $\beta$ - $\mathrm{D}$-galactopyranosyl units. The side chains are composed of two or five 1,3-linked $\beta$-D-galactopyranosyl units, joined to the main chain by 1,6-linkages. Both the main and the side chains contain units of $\alpha$-L-arabinofuranosyl, $\alpha$-L-rhamnopyranosyl, $\beta$-D-glucuronopyranosyl and 4-O-methyl- $\beta$-D-glucuropyranosyl, the last two mostly as end units [13]. The SEM micrograph of gum Arabic is presented in Fig. 1. As seen, the material is composed of lengthened crystals about $15 \mu \mathrm{m}$ in width and $50-60 \mu \mathrm{m}$ in 
length. The EDX elemental analysis shows that C (49.5 wt.\%) and O (43.9 wt.\%) make the highest amount in this binding medium with a smaller amount of $\mathrm{Ca}$ (3.5 wt.\%), $\mathrm{Al}(2.5$ wt.\%) and K (0.6 wt.\%) (Fig. 2). Fish glue, like parchment glue, is a proteinaceous substance that consists of collagen, whose typical microstructure is presented in Fig. 1. The results of the EDX analysis show that fish glue contains C (35.8 wt.\%), O (49.4 wt.\%), $\mathrm{Mg}$ (9.2 wt.\%), $\mathrm{Al}$ (4.4 wt.\%) and small amounts of S (0.9 wt.\%) and Ca (0.3 wt.\%) (Fig.2). These elements can be found as impurities in the remaining production process. Parchment glue is a protein-based material. The SEM image (Fig. 1) presents a monolithic microstructure of this material. According to the EDX analysis, the main elements in the glue are C (68.2 wt.\%) and $\mathrm{O}$ (30.3 wt.\%) (Fig. 2). It also contains $\mathrm{Al}$ (0.6 wt.\%), Ca (0.3 wt.\%), S (0.3 wt.\%) and $\mathrm{Na}(0.3$ wt.\%). These elements may remain over from parchment glue preparation and processing processes.

\section{ATR-FTIR analysis}

The FTIR spectra of all specimens are presented in Figs. 3-5. It is known that the red pigment cinnabar does not absorb infrared radiation in the range of $4000-350 \mathrm{~cm}^{-1}[11]$. However, in the FTIR spectrum of our investigated red pigment cinnabar an intensive absorption band at $1017 \mathrm{~cm}^{-1}$ is observed, which is a characteristic vibration of the $\mathrm{Si}-\mathrm{O}$ bond (Fig. 3). The absorption peaks determined at 692 and $773 \mathrm{~cm}^{-1}$ could be attributed to the Si-O-Al vibrations. No characteristic absorption bands could be seen in the FTIR spectrum of the pigment realgar (Fig. 3). The FTIR spectrum of the pigment red lead presented in Fig. 3 shows the absorption bands in low frequency regions of 682 and $521 \mathrm{~cm}^{-1}$ and one band at $1398 \mathrm{~cm}^{-1}$ which are characteristic of lead oxide [11]. In the FTIR spectrum of the pigment red ochre (Fig. 4) an absorption band at $1030 \mathrm{~cm}^{-1}$, which can be identified as an asymmetric $\mathrm{Si}-\mathrm{O}-\mathrm{Si}$ stretching band, is seen. The peak at $795 \mathrm{~cm}^{-1}$ is due to vibrations of $\mathrm{Si}-\mathrm{O}-\mathrm{Al}$. The absorption bands located at 431 and $531 \mathrm{~cm}^{-1}$ could probably be attributed to the $\mathrm{Fe}-\mathrm{O}$ vibrations in iron oxide [11]. The FTIR spectrum of the pigment hematite (Fig. 4) also shows the characteristic absorption bands of iron oxide at the wavenumbers of 431 and $519 \mathrm{~cm}^{-1}$. The absorption bands visible

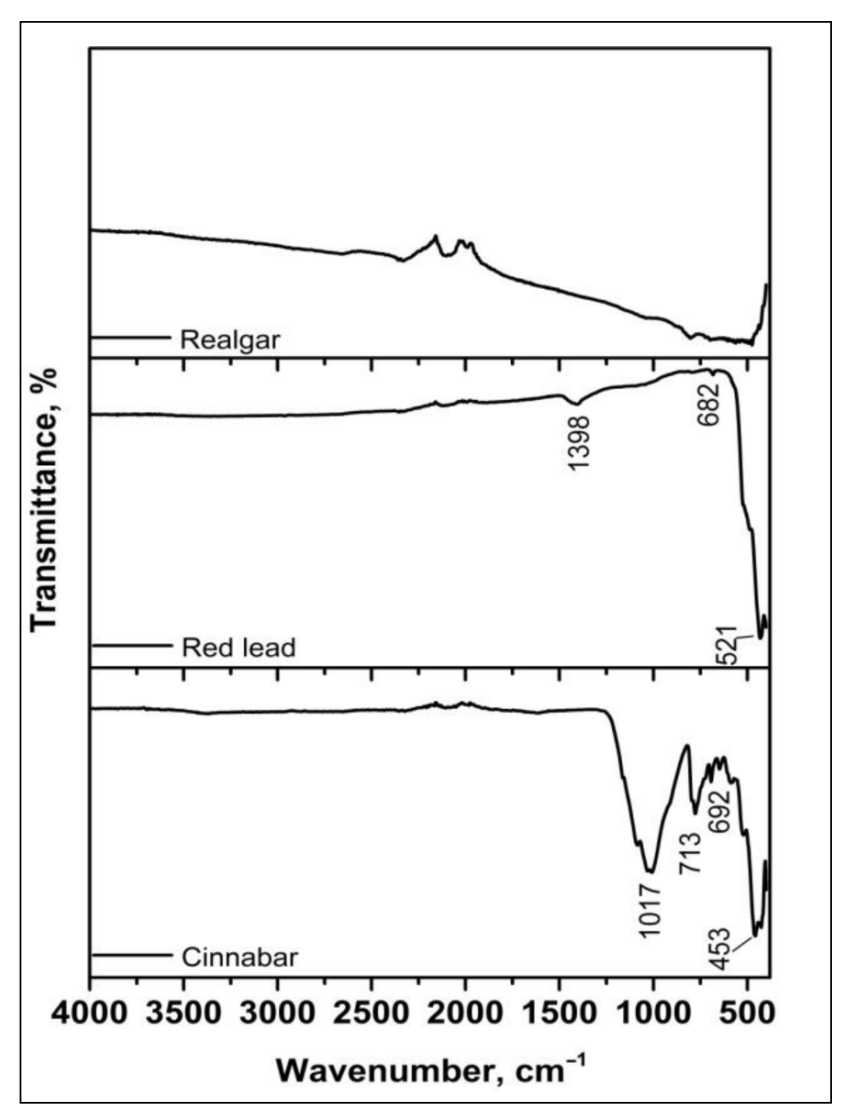

Fig. 3. FTIR spectra of the pigments realgar, red lead and cinnabar

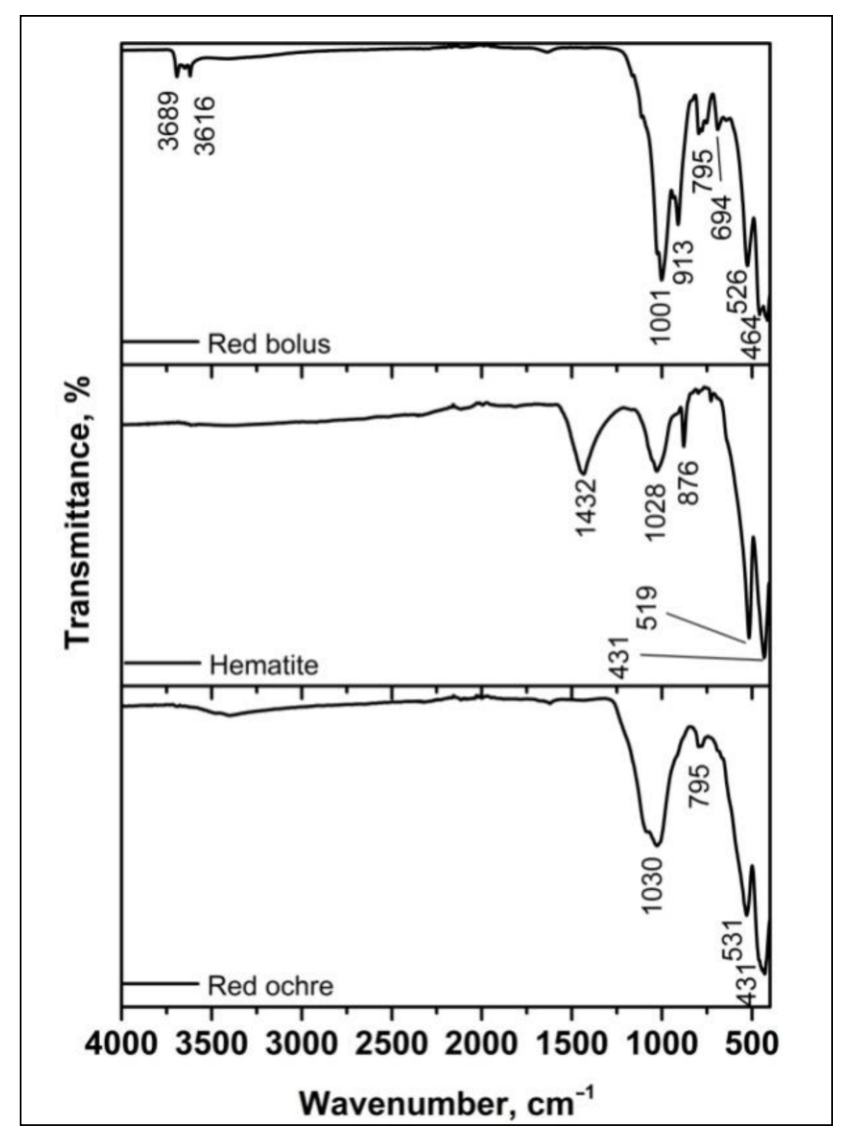

Fig. 4. FTIR spectra of the pigments red bolus, hematite and red ochre 


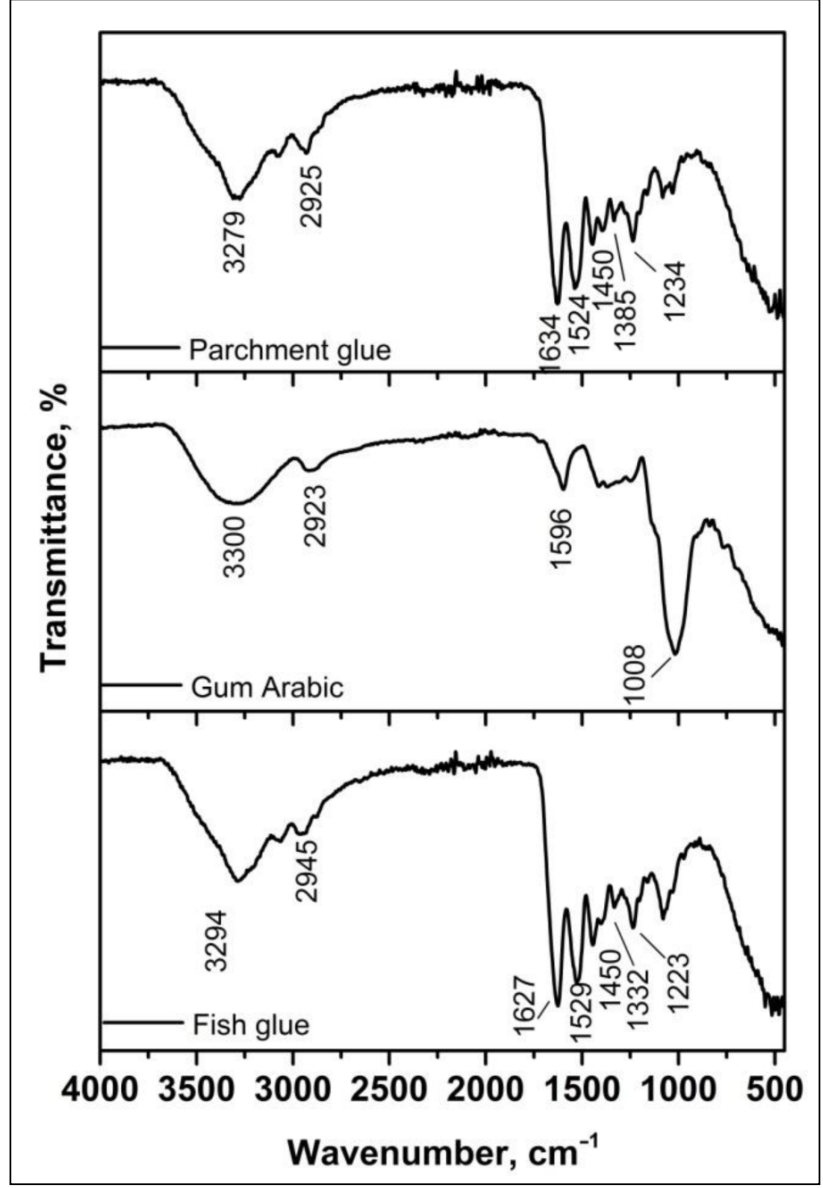

Fig. 5. FTIR spectra of the binding media: parchment glue, gum Arabic and fish glue

at 876 and $1432 \mathrm{~cm}^{-1}$ are due to the vibrations in ionic carbonate $\left(\mathrm{CaCO}_{3}\right)$. Again, an absorption band at $1028 \mathrm{~cm}^{-1}$ could be identified as an asymmetric Si-O-Si stretching band [11]. The FTIR spectrum of the pigment red bolus is shown in Fig. 4. The spectrum represents the absorption bands characteristic of kaolin $\left(\mathrm{Al}_{2} \mathrm{Si}_{2} \mathrm{O}_{5}(\mathrm{OH})_{4}\right)$ : the $\mathrm{O}-\mathrm{H}$ stretching bands are located at 3689 and at $3616 \mathrm{~cm}^{-1}$, an asymmetric $\mathrm{Si}-\mathrm{O}-\mathrm{Si}$ stretching band at $1001 \mathrm{~cm}^{-1}$ and $\mathrm{Si}-\mathrm{O}$ stretching bands at $913 \mathrm{~cm}^{-1}$. The absorption peaks visible at 694 and $795 \mathrm{~cm}^{-1}$ are due to the $\mathrm{Si}-\mathrm{O}-\mathrm{Al}$ vibrations and at 464 and $526 \mathrm{~cm}^{-1}$ are due to the $\mathrm{Fe}-\mathrm{O}$ vibrations [11].

In the FTIR spectrum of gum Arabic (Fig. 5) the intensive absorption bands at 3300 and $1008 \mathrm{~cm}^{-1}$ are the characteristic stretching vibrations of the $\mathrm{O}-\mathrm{H}$ bond [14]. The band at $2923 \mathrm{~cm}^{-1}$ is due to the characteristic vibrations of $\mathrm{C}-\mathrm{H}$. The absorption peak at $1596 \mathrm{~cm}^{-1}$ could be attributed to the vibration of the double bond in $\mathrm{C}=\mathrm{O}$. The FTIR spectra of parchment and fish glue (Fig. 5) are almost identical, since collagen is the main component of these materials. The absorption bands determined at 3279 and $3294 \mathrm{~cm}^{-1}$ are the characteristic valentic vibration of the $\mathrm{O}-\mathrm{H}$ bond. The bands at 2945 and $2925 \mathrm{~cm}^{-1}, 1480$ to $1300 \mathrm{~cm}^{-1}$ could be attributed to the vibrations of $\mathrm{C}-\mathrm{H}$. The absorption bands of amides coupled to $\mathrm{C}=\mathrm{O}$ are seen at $1627,1634 \mathrm{~cm}^{-1}$ (amide I), at 1524 , $1529 \mathrm{~cm}^{-1}$ (amide II) and at $1223,1234 \mathrm{~cm}^{-1}$ (amide III) [15].

\section{XRD analysis}

The X-ray diffraction pattern of cinnabar is presented in Fig. 6. The diffractogram shows that the purchased pigment cinnabar with the main HgS phase (PDF 00-075-1589) also

Fig. 6. The XRD pattern of cinnabar, $\diamond \mathrm{SiO}_{2}$

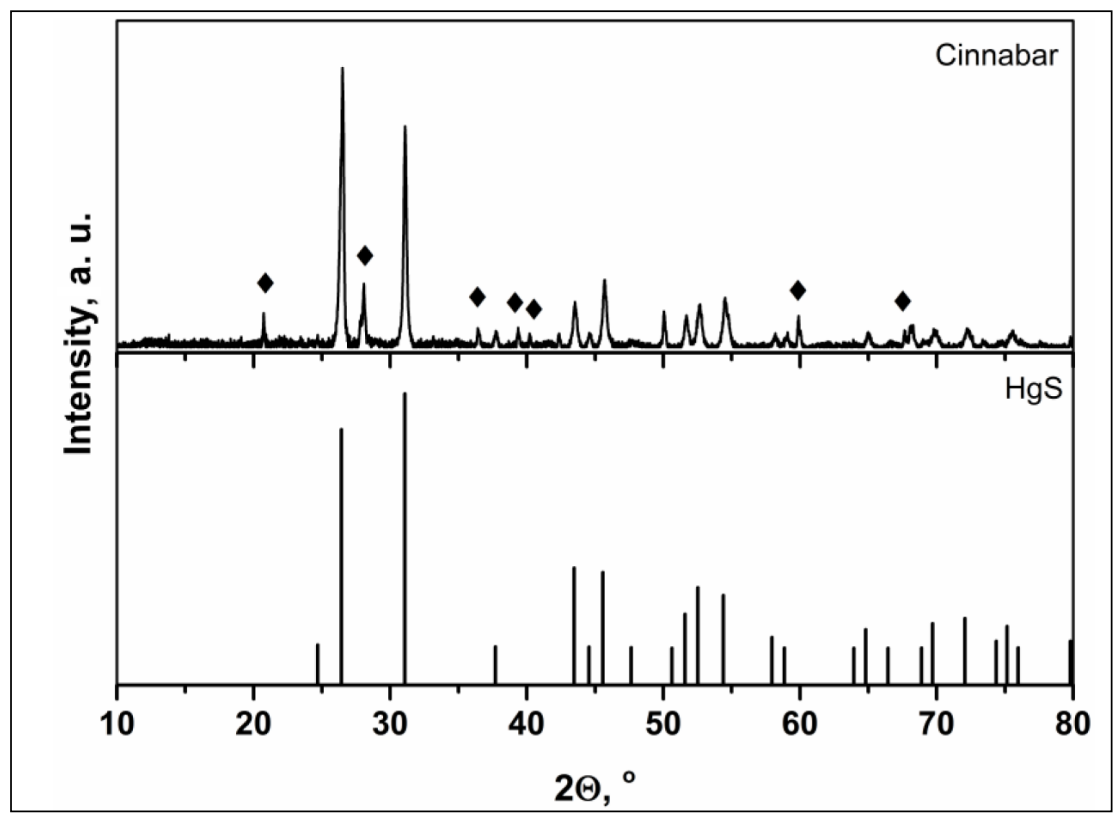


contains an additional $\mathrm{SiO}_{2}$ phase (PDF 00-0781253). These results confirm the results obtained by SEM-EDX and FTIR spectroscopy. The XRD pattern of the pigment red ochre is shown in Fig. 7 .

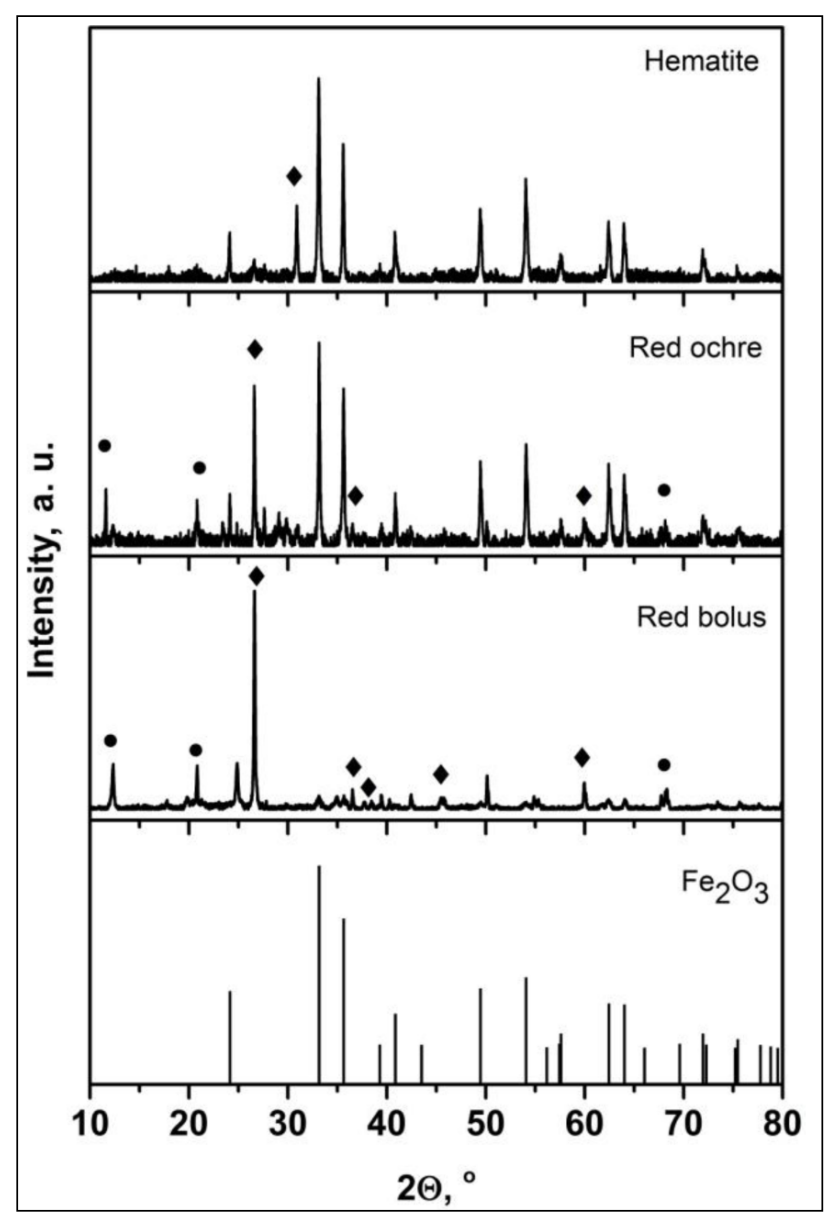

Fig. 7. The XRD patterns of hematite, red ochre and red bolus, $\diamond \mathrm{SiO}_{2^{\prime}}$ - $\mathrm{Al}_{2} \mathrm{Si}_{2} \mathrm{O}_{5}(\mathrm{OH})_{4}$

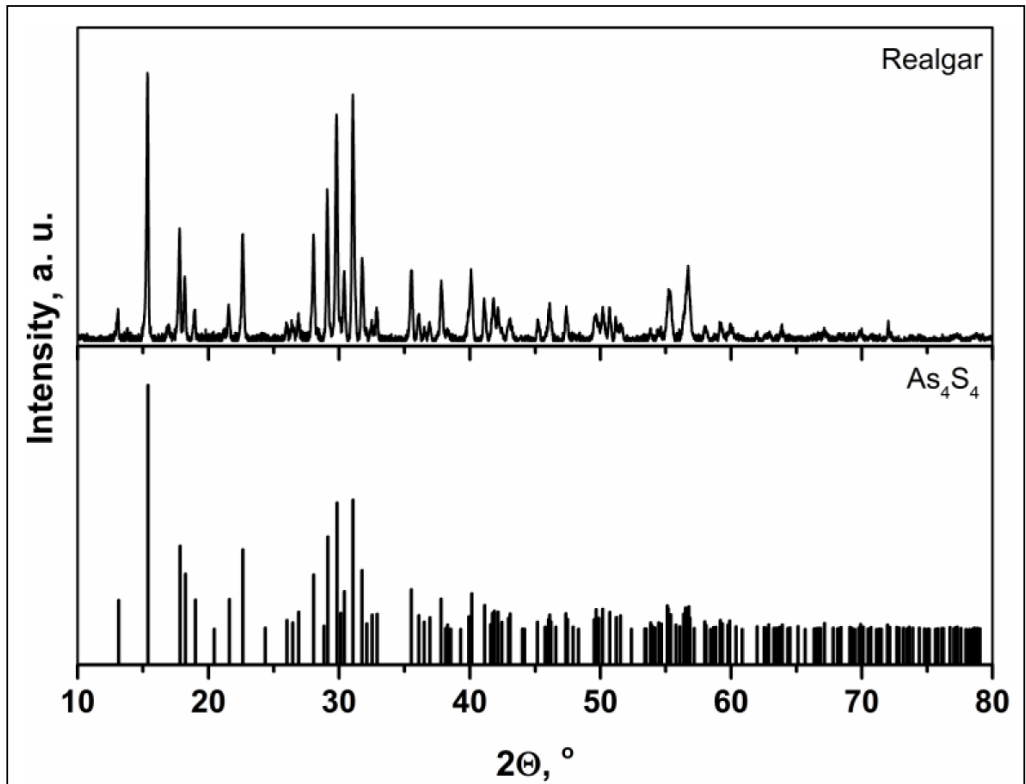

As seen, the main phase in red ochre is $\mathrm{Fe}_{2} \mathrm{O}_{3}$ (PDF 00-033-0664), but the additional crystalline $\mathrm{Al}_{2} \mathrm{Si}_{2} \mathrm{O}_{5}(\mathrm{OH})_{4}$ phase (PDF 00-075-1593) and the impurity $\mathrm{SiO}_{2}$ phase are also present in the pigment. The pigment hematite also contains the impurity $\mathrm{SiO}_{2}$ phase (see Fig. 7), while the pigment red bolus contains three $\mathrm{Fe}_{2} \mathrm{O}_{3}, \mathrm{SiO}_{2}$ and $\mathrm{Al}_{2} \mathrm{Si}_{2} \mathrm{O}_{5}(\mathrm{OH})_{4}$ phases (see Fig. 7). As seen from Fig. 8, the pigment realgar consists only of $\mathrm{As}_{4} \mathrm{~S}_{4}$ (PDF 00-072-0686). The pigment red lead (see Fig. 9) also consists only of $\mathrm{Pb}_{3} \mathrm{O}_{4}$ (PDF 00-041-1493). Thus, according to the results of the XRD, SEM-EDX and FTIR analysis results the chemical composition of the pigments realgar and red lead purchased from Kremer Pigmente corresponds to that described in the catalogue. The rest four pigments, however, contain different impurities.

It is known that for pure gum Arabic, the main diffraction line in the XRD pattern is located at $18.9^{\circ} 2 \theta[16]$. As mentioned before, collagen is the main component of parchment and fish glue. Two diffraction lines of collagen are at $7^{\circ} 2 \theta$, which is indicative of the position of the characteristic equatorial peak of collagen and a broad peak at $20^{\circ} 2 \theta$ indicates the position of the characteristic interchain spacing of the collagen triple helix [17, 18]. In our investigated samples, the characteristic diffraction peaks are slightly shifted, because a small amount of inorganic impurities is in the composition of the materials (see Fig. 10).

Fig. 8. The XRD pattern of realgar 

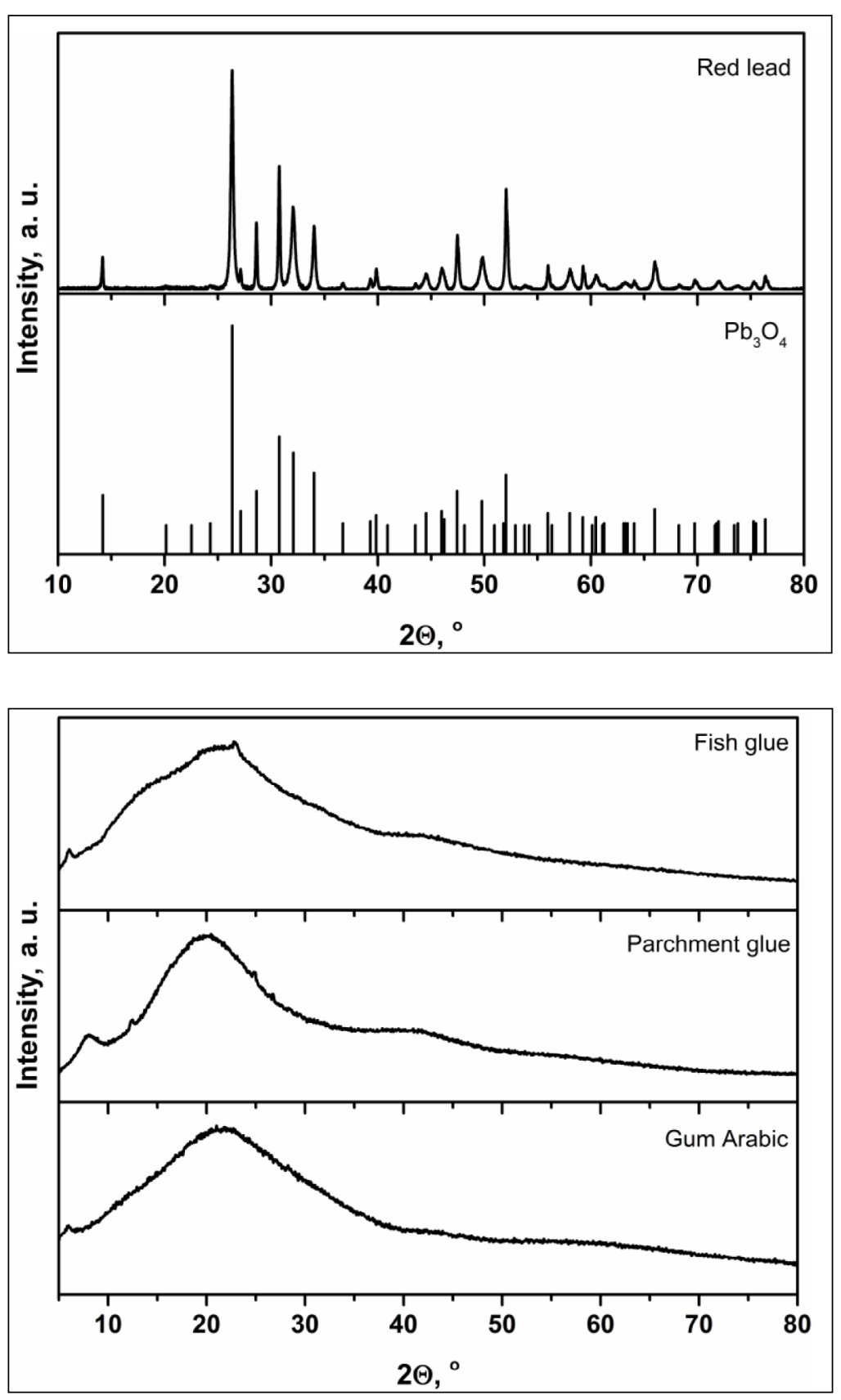

Fig. 9. The XRD pattern of red lead

Fig. 10. The XRD patterns of gum Arabic, parchment and fish glue

\section{TG/DTG/DSC analysis}

The TG/DTG/DSC curves of cinnabar are shown in Fig. 11. Hexagonal red mercury sulphide $\alpha-\mathrm{HgS}$ rearranges to the black mercury sulphide $\beta-\mathrm{HgS}$ having a cubic crystal structure in the temperature range of $300-410^{\circ} \mathrm{C}$. The first and the main mass loss (about 55\%) is observed at about $400^{\circ} \mathrm{C}$. This event is associated with the sublimation of black $\beta$-HgS with the following formation of metacinnabar mixed with other black amorphous product [19, 20]. The TG/DTG/DSC curves of red bolus, red ochre and hematite are presented in Figs. 12-14. Differences in the thermal analysis curves are evident, despite the com- position of the materials investigated is very similar. Of course, the differences are mainly caused by the presence of impurities. The red pigments contain the $\mathrm{Al}_{2} \mathrm{Si}_{2} \mathrm{O}_{5}(\mathrm{OH})_{4}$ impurity phase which decomposes monotonically by heating the sample up to $700-800^{\circ} \mathrm{C}$. Moreover, hematite according to the FTIR results also contains calcium carbonate which decomposes between 600 and $700^{\circ} \mathrm{C}$. The mass loss in all cases was found to be about 6-7\%. Figure 15 shows the TG/DTG/DSC curves of red lead. Red lead forms through an oxidation process when $a-\mathrm{PbO}$ is heated to around 450 $500^{\circ} \mathrm{C}$, but decomposes at atmospheric pressure to yellow litharge ( $\beta-\mathrm{PbO}$, orthorombic) when 


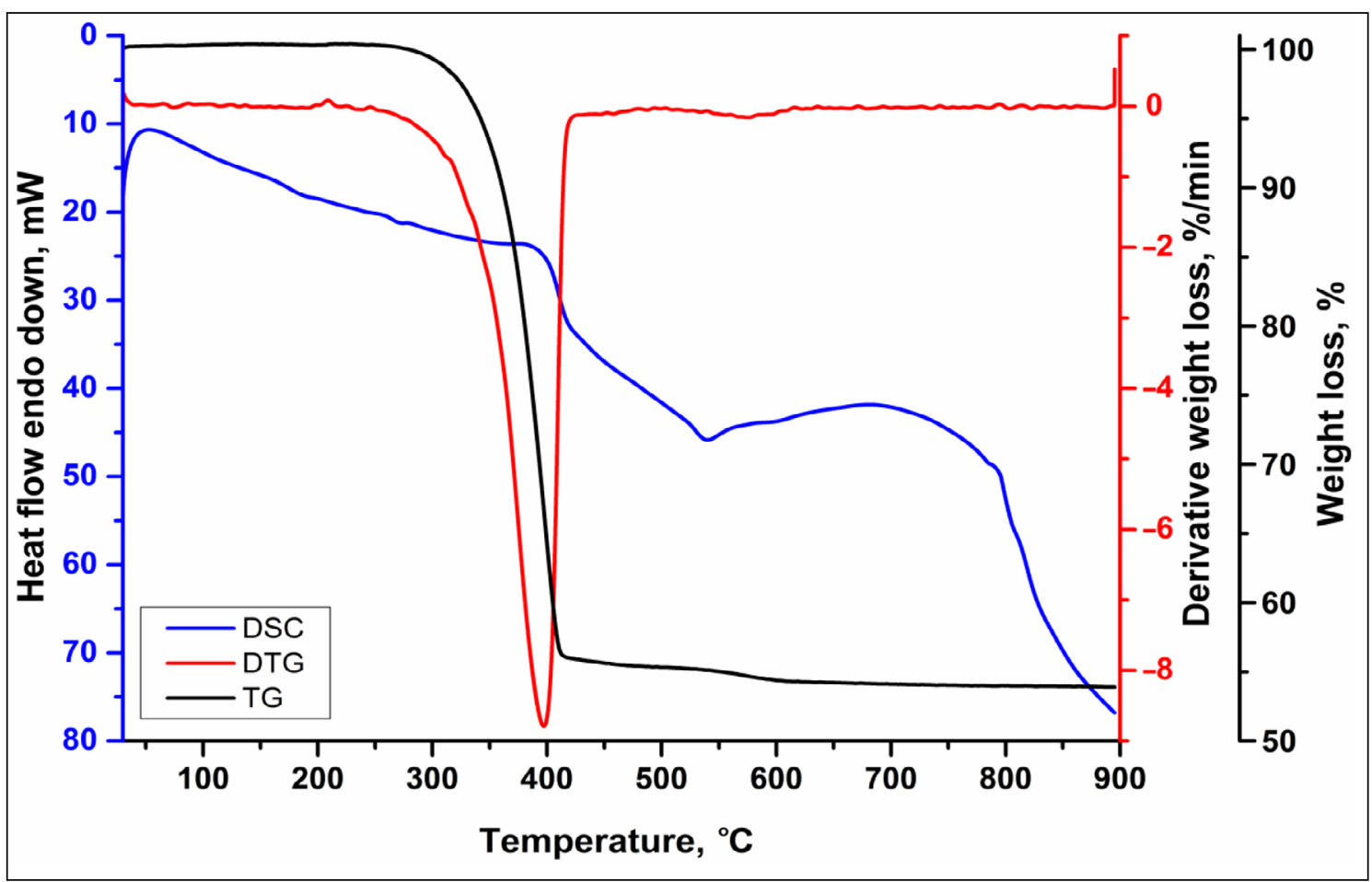

Fig. 11. The $T G / D T G / D S C$ curves of cinnabar

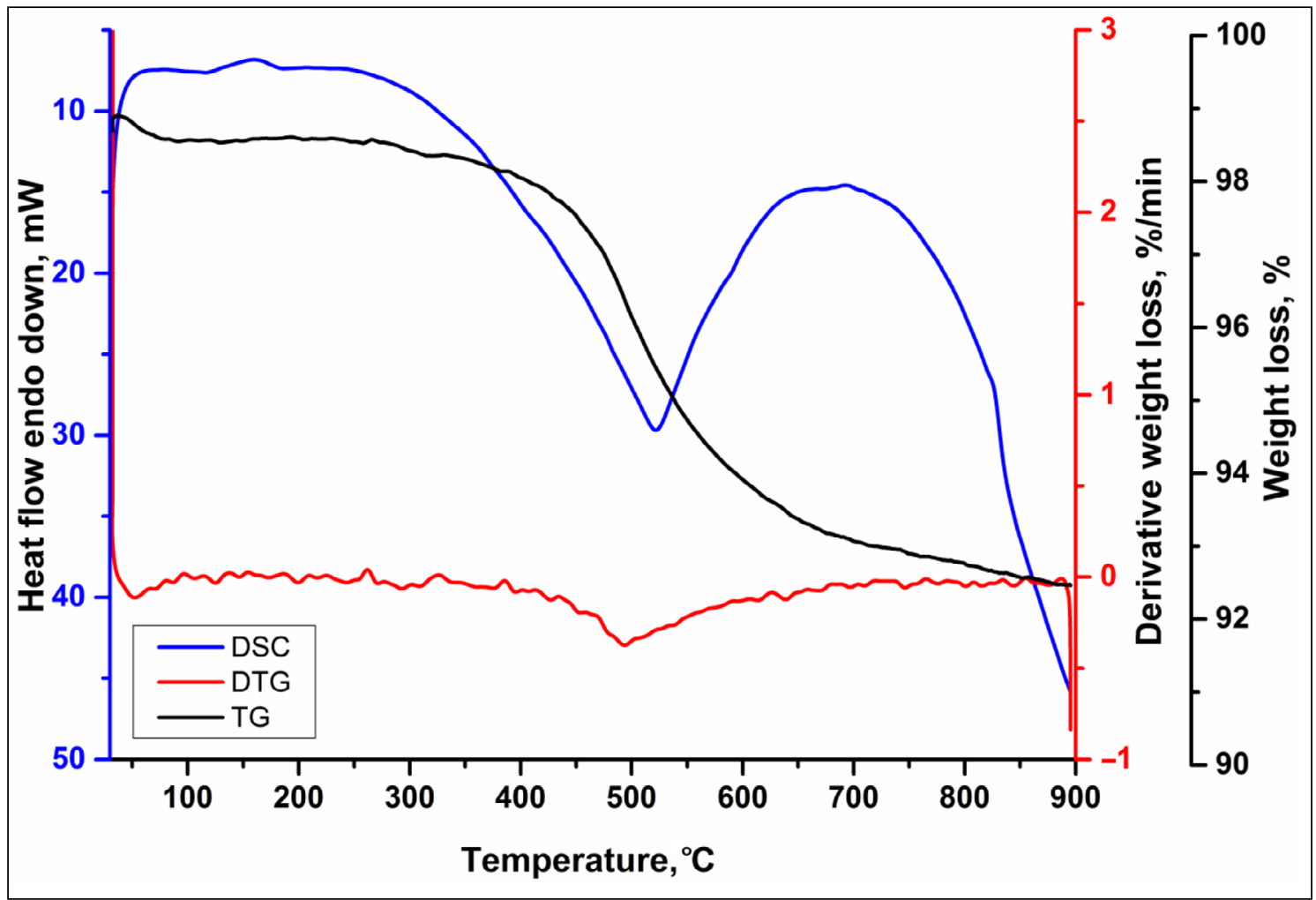

Fig. 12. The TG/DTG/DSC curves of red bolus

temperature exceeds $585^{\circ} \mathrm{C}$ [21]. The mass loss the TG curve of the pigment realgar (Fig. 16), during the decomposition of $\mathrm{Pb}_{3} \mathrm{O}_{4}$ to the $\mathrm{PbO}$ the mass loss starts at $307^{\circ} \mathrm{C}$ and continuously lasts process was determined about $2 \%$. As seen from untill $100 \%$ of mass is lost at about $450-500^{\circ} \mathrm{C}$. 


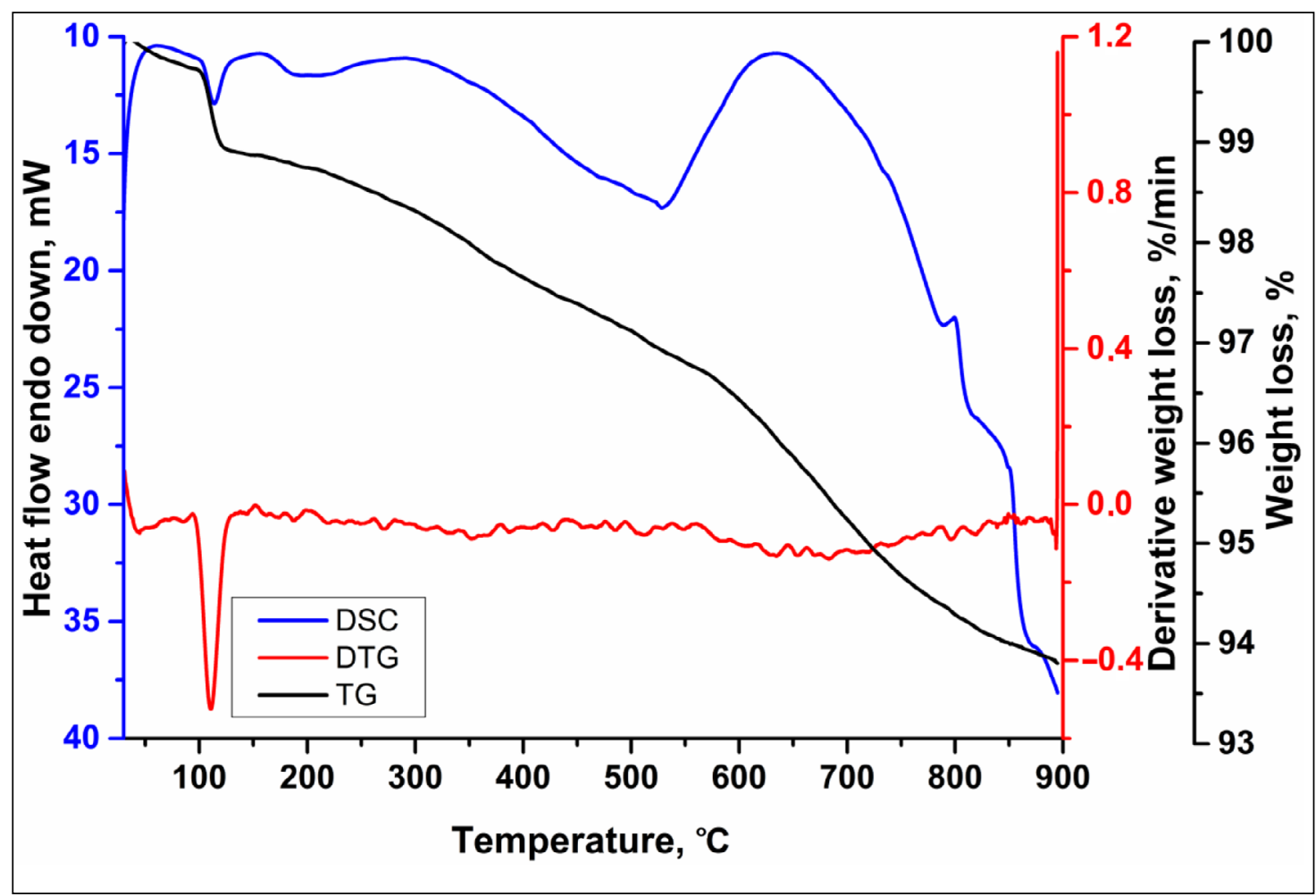

Fig. 13. The TG/DTG/DSC curves of red ochre

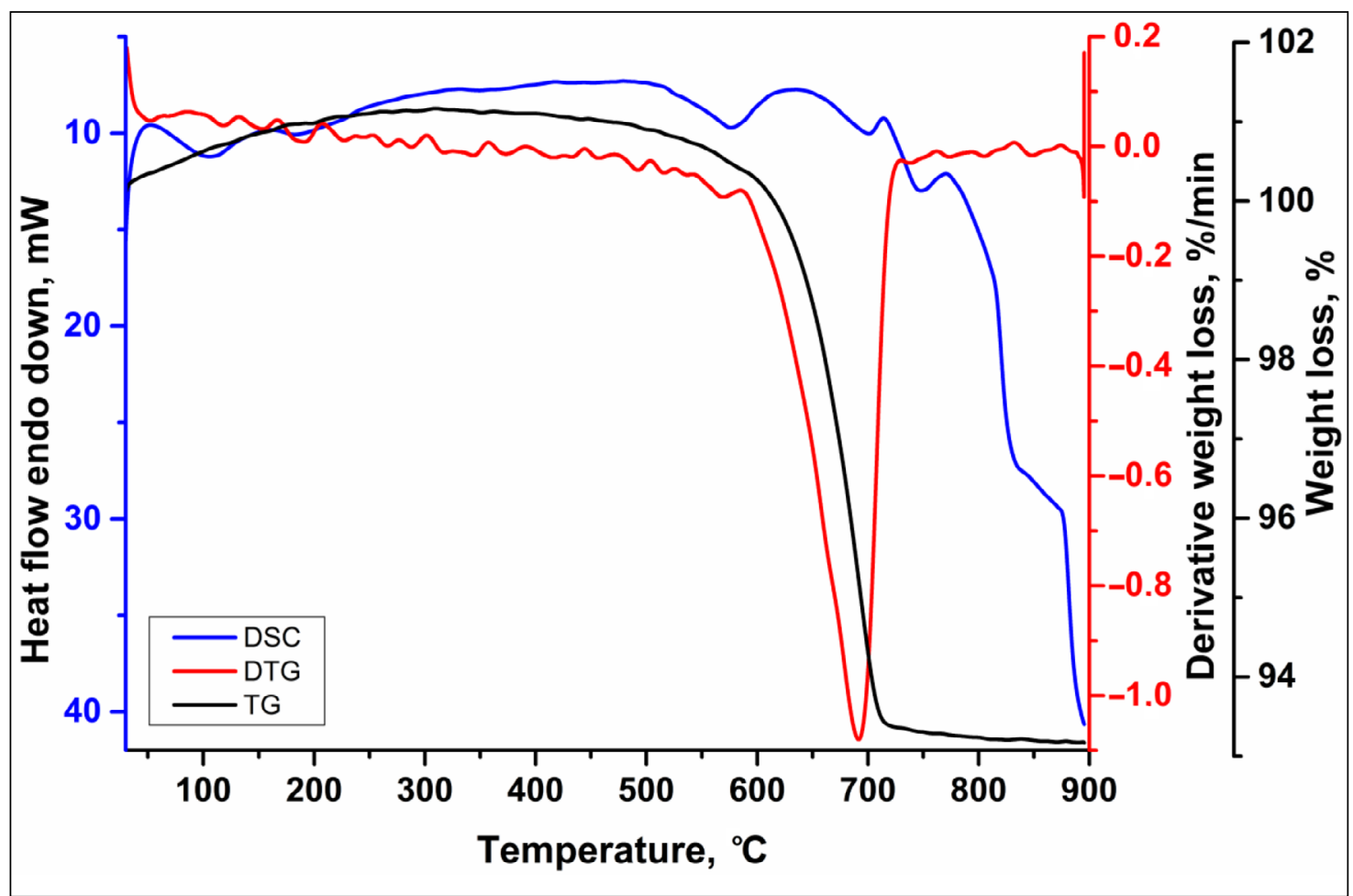

Fig. 14. The TG/DTG/DSC curves of hematite

Realgar $\left(\alpha-\mathrm{As}_{4} \mathrm{~S}_{4}\right)$ at about $256^{\circ} \mathrm{C}$ temperature under loss observed in this stage is about $10 \%$. The next normal pressure transforms to the $\beta$-As $\mathrm{S}_{4}$ phase, which melts at about $307^{\circ} \mathrm{C}$ temperature. The mass step of mass loss in the range of about $390-430^{\circ} \mathrm{C}$ (55\%) could be associated with the transformation 


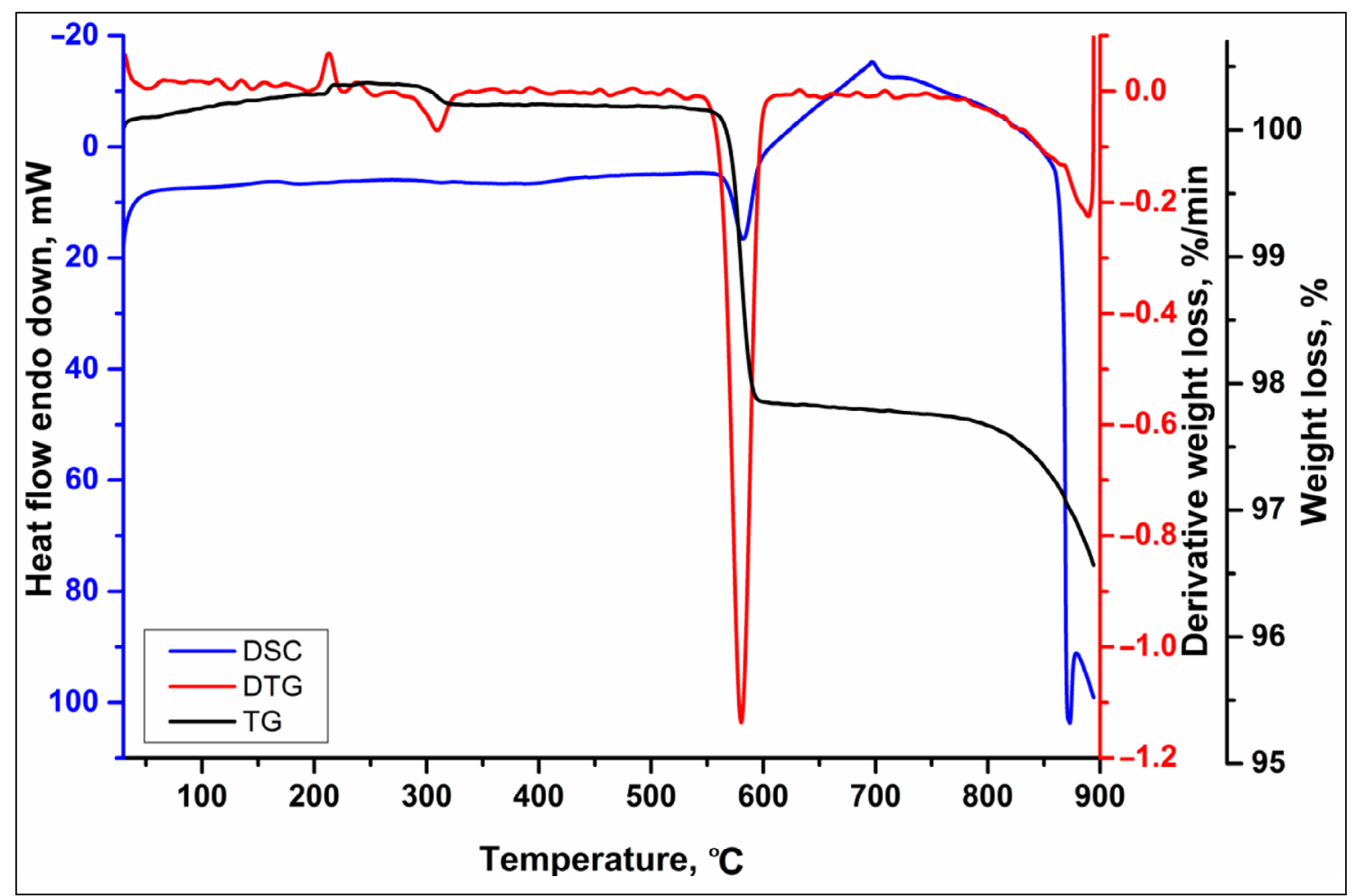

Fig. 15. The TG/DTG/DSC curves of red lead

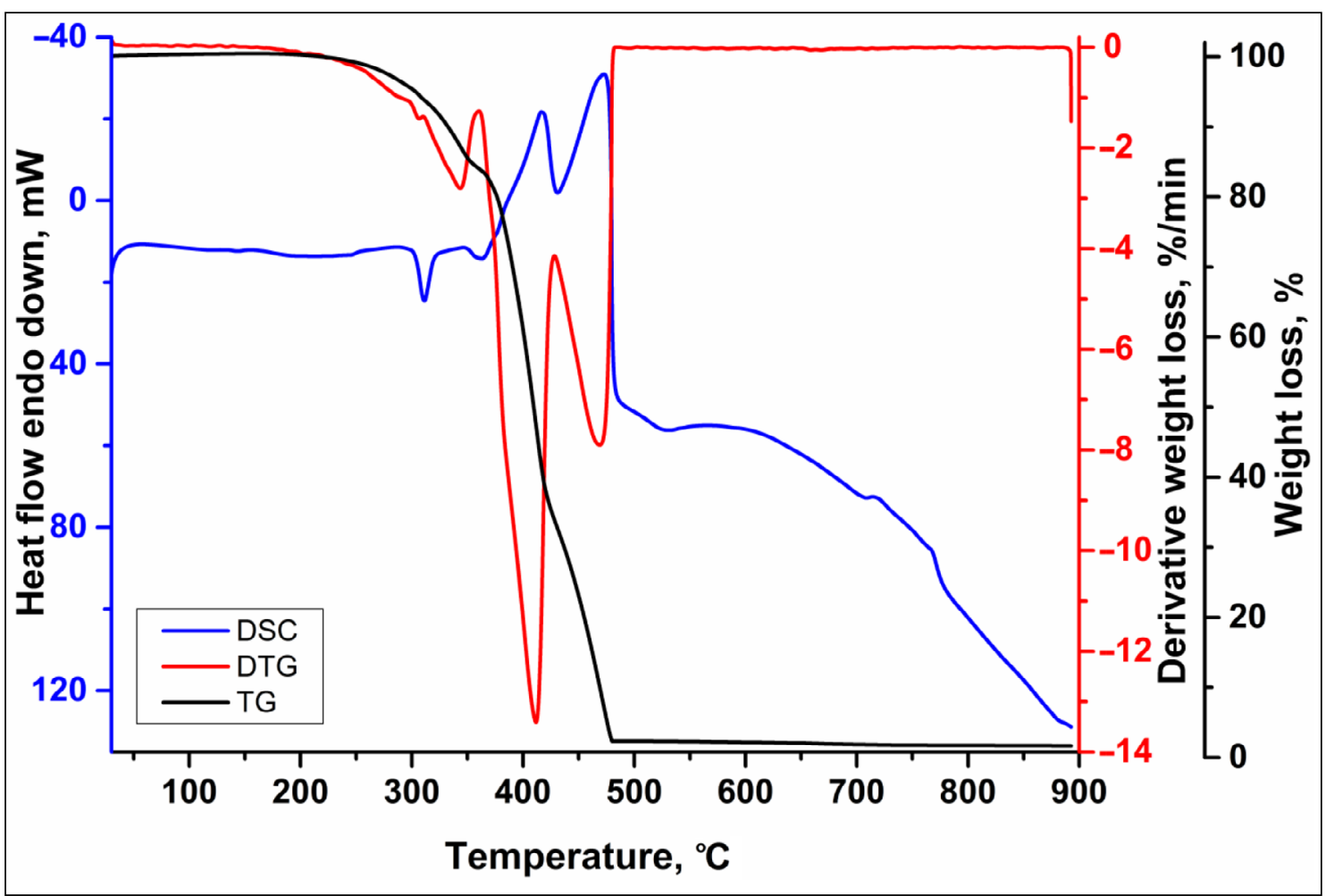

Fig. 16. The TG/DTG/DSC curves of realgar

of the $\beta-\mathrm{As}_{4} \mathrm{~S}_{4}$ phase to arsenolite. And finally, the material formed starts to evaporate, in the temperature range of $450-500^{\circ} \mathrm{C}$ [22].
Figures 17 and 18 show the TG/DTG/DSC curves of parchment and fish glue. The thermal behaviour of parchment and fish glue are very similar during 


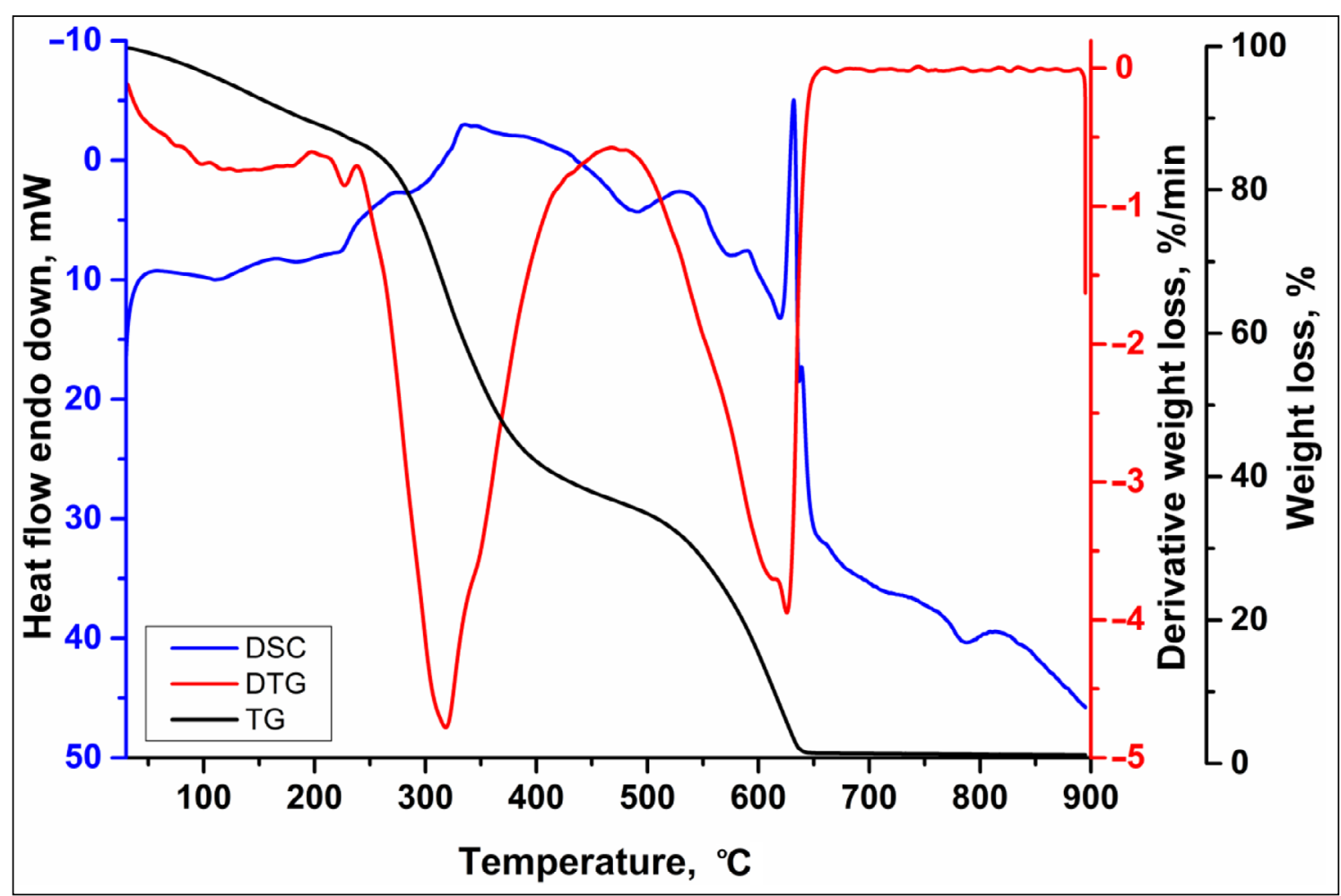

Fig. 17. The TG/DTG/DSC curves of parchment glue

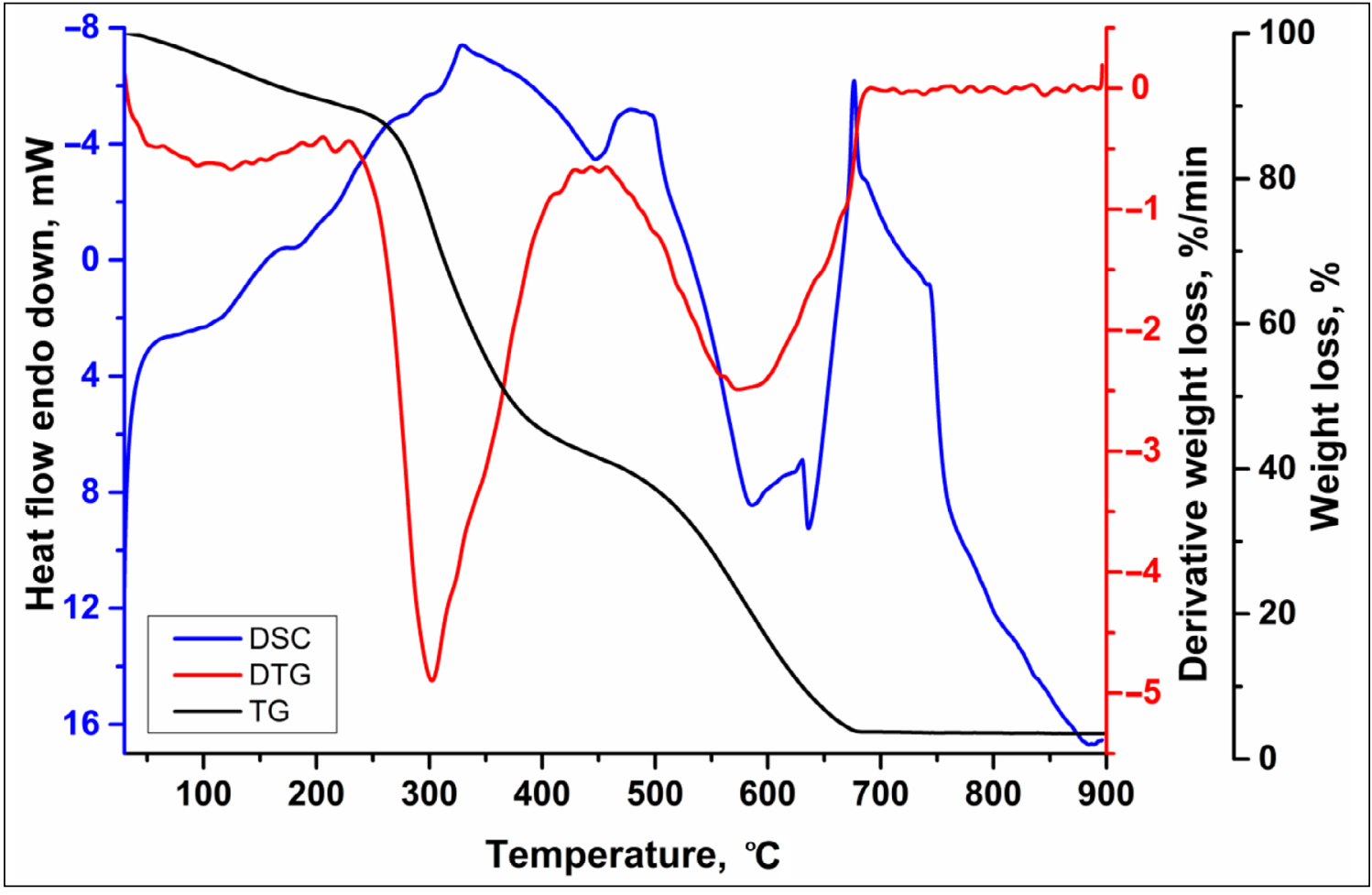

Fig. 18. The TG/DTG/DSC curves of fish glue

the heating procedure. The main reason of the different behaviour probably lies in the different preparation method or naturally aged process. The main and broad DTG peak attributed to the thermal decomposition of collagen is located between 200 and $650^{\circ} \mathrm{C}$. The first step of mass loss can be attributed 


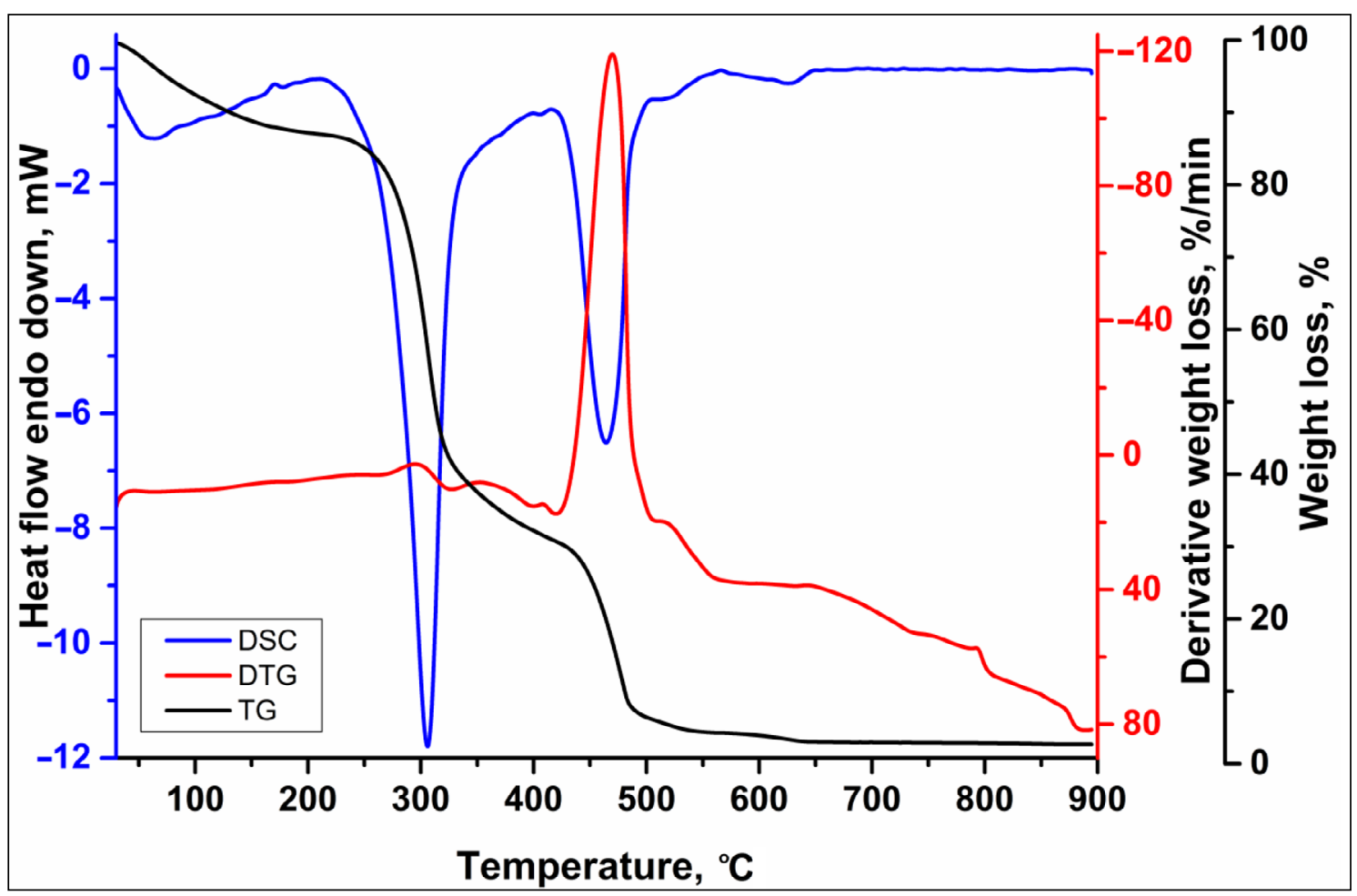

Fig. 19. The $T G / D T G / D S C$ curves of gum Arabic

to the release of traces of the so-called structurally bound water and decomposition of hydroxyl groups present in the collagen molecule. At higher temperatures, intermediate inorganic compounds decompose $23-26$. In Fig. 19 the TG/DTG/DSC curves of gum Arabic are presented. Three main mass losses are visible in the TG curve. The first mass loss $(10-15 \%)$ is due to the loss of adsorbed and structural water of gums and is observed between 30 and $150^{\circ} \mathrm{C}$. The second mass loss of about $50 \%$ at $260-350^{\circ} \mathrm{C}$ is related with the decomposition of polysaccharide [27, 28]. The final mass loss (30\%) in the temperature range of $400-600^{\circ} \mathrm{C}$ could be associated with the thermal decomposition of intermediate residues formed in the carboxymethylated samples with inorganic compounds [29].

\section{CONCLUSIONS}

In this study, six different red pigments (natural cinnabar $(\mathrm{HgS})$, red lead $\left(\mathrm{Pb}_{3} \mathrm{O}_{4}\right)$, realgar $\left(\mathrm{As}_{4} \mathrm{~S}_{4}\right)$, red bolus $\left(\mathrm{Fe}_{2} \mathrm{O}_{3} \cdot \mathrm{SiO}_{2} \cdot \mathrm{Al}_{2} \mathrm{O}_{3}\right)$, red ochre $\left(\mathrm{Fe}_{2} \mathrm{O}_{3}\right)$ and hematite $\left(\mathrm{Fe}_{2} \mathrm{O}_{3}\right)$ ), and three binding media (gum Arabic, fish glue and parchment glue) purchased from Kremer Pigmente were investigated and characterized using Fourier-transform infrared spectroscopy (FTIR), scanning electron microscopy coupled with energy-dispersive X-ray spectroscopy (SEM/ EDX), X-ray diffraction (XRD) analysis and thermal (TG/DTG/DSC) analysis techniques. The SEM micrographs showed that the surface microstructure of pigments and binding media depends very much on the nature of materials. The EDX results demonstrated the presence of side chemical elements in the investigated specimens, while the FTIR spectra showed additional absorption bands. Finally, the XRD results were in a good agreement with the SEM-EDX and FTIR analysis results confirming that the chemical composition of realgar and red lead pigments purchased from Kremer Pigmente corresponded to that described in the catalogue. The rest four pigments, however, contained different impurities. The obtained results will be used for the analysis of different model compositions of red paints. Finally, these analytical data will be used for the identification of specimens obtained from ancient manuscripts.

\section{ACKNOWLEDGEMENTS}

This research was funded by a grant SINALAN (No. S-LU-18-13) from the Research Council of Lithuania.

Received 23 August 2018 Accepted 24 September 2018 


\section{References}

1. J. R. Barnett, S. Miller, E. Pearce, Opt. Laser Technol., 38, 445 (2006).

2. A. Wallert, E. Hermens, M. F. J. Peek (eds.), Historical Painting Techniques, Materials, and Studio Practice: Preprints of a Symposium held at the University of Leiden, the Netherlands, 26-29 June, Getty Conservation Institute (1995).

3. E. Gražènaitè, J. Kiuberis, A. Beganskienè, et al., Chemija, 25, 199 (2014).

4. O. Opuchovic, G. Kreiza, J. Senvaitienè, et al., Dyes Pigm., 118, 176 (2015).

5. A. Gatelytè, J. Senvaitiene், D. Jasaitis, et al., Chemija, 22, 19 (2011).

6. J. Senvaitienè, A. Beganskienè, A. Kareiva, Vibr. Spectrosc., 37, 61 (2005).

7. D. M. Goltz, Anal. Lett., 45, 314 (2012).

8. J. Senvaitienè, A. Beganskienè, L. SalickaitèBunikienè, et al., Lith. J. Phys., 46, 109 (2006).

9. J. Senvaitienè, I. Pakutinskienè, A. Beganskienè, et al., Polish J. Chem., 79, 1575 (2005).

10. M. Aceto, A. Agostino, G. Fenoglio, et al., Anal. Methods, 6, 1488 (2014).

11. A. Vila, J. F. Garcia, Anal. Lett., 45, 1274 (2012).

12. R. Klockenkamper, A. von Bohlen, L. Moens, X-Ray Spectrom., 29, 119 (2000).

13. C. Sanchez, M. Nigen, V. M. Tamayo, et al., Food Hydrocoll., 78, 140, (2018).

14. Y. Don, K. M. Sørensen, S. He, S. Balling Engelsen, Food Control, 78, 144 (2017).

15. B. de Campos Vidal, M. L. S. Mello, Micron, 42, 283 (2011).

16. F. Niua, M. Koua, J. Fana, et al., Food Chem., 260, 1 (2018).

17. N. Davidenko, J. J. Campbell, E. S. Thian, et al., Acta Biomater., 6, 3957 (2010).

18. K. Wang, W. Wang, R. Ye, et al., Food Chem., 216, 209 (2017).

19. C. Miguel, J. V. Pinto, M. Clarke, et al., Dyes Pigm., 102, 210 (2014).

20. The Book on How to Make Colours https:// www.dcr.fct.unl.pt/sites/www.dcr.fct.unl.pt/files/ ArquivoDigital/como\%20fazer\%20as\%20cores\%20 cap\%20livro/LKSK_full\%20pdf.pdf].
21. J. P. McKinley, M. K. Dlaska, R. Batson, J. Power Sources, 107, 180 (2002).

22. M. Zoppi, G. Pratesi, Am. Mineral., 97, 890 (2012).

23. Z. Sebestyén, Z. Czégény, E. Badea, et al., J. Anal. Appl. Pyrolysis, 115, 419 (2015).

24. M. Tomassetti, F. Marini, L. Campanella, et al., Microchem. J., 108, 7 (2013).

25. K. M. Axelsson, R. Larsen, D. V. P. Sommer, J. Cult. Herit., 13, 128 (2012).

26. P. Budrugea, E. Badea, G. Della Gatta, et al., Thermochim. Acta, 500, 51 (2010).

27. J. Jamaludin, F. Adam, R. Abdul Rasid, et al., Chem. Eng. Res. Bull., 19, 80 (2017).

28. R. M. A. Daoub, A. H. Elmubarak, M. Misran, et al., J. Saudi Soc. Agr. Sci., 17, 241 (2018).

29. D. A. Silva, J. P. A. Feitosa, J. S. Maciel, et al., Carbohydr. Polym., 66, 16 (2006).

\section{Aušra Čiuladienė, Austėja Luckutė, Jonas Kiuberis, Aivaras Kareiva \\ RAUDONŲJŲ PIGMENTŲ IR RIŠAMŨJŲ MEDŽIAGŨ CHEMINĖS SUDĖTIES TYRIMAS}

Santrauka

Pirmą kartą buvo analizuoti šeši raudoni pigmentai (cinoberis, hematitas, raudonasis molis, raudonoji ochra, realgaras ir švino minija) bei trys rišamosios medžiagos (gumiarabikas, pergamento ir žuvų klijai), ịsigyti iš Kremer Pigmente. Ivairiais laikotarpiais šios medžiagos buvo naudojamos senųjų rankraščių ir knygų puošybai (rubrikoms, iliuminacijoms). Medžiagos tirtos Furje infraraudonosios spektroskopijos (FTIR), skenuojančios elektrononinès mikroskopijos su rentgeno spindulių energijos dispersine spektrometrija (SEM/EDX), rentgeno spindulių difrakcinès (XRD) analizès ir terminès (TG/DTG/DSC) analizès metodais. Gauti rezultatai parodè, kad realgaro ir švino minijos cheminès sudètys atitiko pateiktoms Kremer Pigmente kataloge. Tačiau kitų tirtų raudonųjų pigmentų sudètyje rasti ịvairūs kiekiai priemaišinių medžiagų. Gauti duomenys bus naudojami kurti ir analizuoti skirtingų raudonųjų dažų modelių kompozicijas. Be to, šie raudonųjų pigmentų ir rišamųjų medžiagų cheminès sudèties tyrimo duomenys bus naudojami senovinių rankraščių pavyzdžiams identifikuoti. 
